\title{
Human Serum Paraoxonase (PON-1) and hemochromatosis gene (HFE) gene polymorphisms in occupationally exposed lead workers from Saudi Arabia
}

\author{
A.P. Shaik ${ }^{1}$, A.H. Alsaeed ${ }^{1}$, M. Faiyaz-ul-Haque ${ }^{2}$, M.A. Alsaeed ${ }^{3}$ and \\ A.S. Shaik ${ }^{1}$ \\ ${ }^{1}$ Department of Clinical Laboratory Sciences, King Saud University, \\ Riyadh, Saudi Arabia \\ ${ }^{2}$ Department of Pathology, College of Medicine, King Saud University, \\ Riyadh, Saudi Arabia \\ ${ }^{3}$ King Saud bin Abdulaziz University for Health Sciences, Riyadh, Saudi \\ Arabia \\ Corresponding author: A.P. Shaik \\ E-mail: ashaik@ksu.edu.sa
}

Genet. Mol. Res. 18 (2): gmr18317

Received April 03, 2019

Accepted June 25, 2019

Published June 30, 2019

DOI http://dx.doi.org/10.4238/gmr18317

\begin{abstract}
Serum paraoxonase (PON1) and hemochromatosis (HFE) genes may play important roles in lead toxicity owing to their role in xenobiotic and iron metabolism, respectively. The association between PON1 and HFE genotypes and blood lead levels (BLLs) was examined in lead exposed subjects from Saudi Arabia. The polymorphisms at PON1 L55M, PON1 Q192R, HFE H63D and HFE C282Y (using PCR-RFLP) and their relation to BLLs was evaluated. The recruited subjects $(\mathrm{N}=127)$ were categorized into low BLL group $(<10 \mu \mathrm{g} / \mathrm{dL})$ and high BLL group $(>10 \mu \mathrm{g} / \mathrm{dL})$ according to CDC guidelines. The low BLL group had a mean level of $3.94 \mu \mathrm{g} / \mathrm{dL}$, while the high BLL group had levels of $15.33 \mu \mathrm{g} / \mathrm{dL}(\mathrm{P}<0.001)$. Overall, the genetic variants, TA and AA in the PON1 L55M were significantly $(\mathrm{P}=0.00002$ and $\mathrm{P}=0.00322$, respectively) associated with a risk of lead toxicity and the allele ' $\mathrm{A}$ ' was a risk factor $(\mathrm{P}=$ 0.00002). However, the Q192R genotype of PON1 along with HFE
\end{abstract}


H63D and HFE C282Y did not significantly increase the risk of developing lead poisoning. Our findings suggest that L55M gene polymorphism influences the susceptibility of subjects to lead exposure and thus it could be a useful biomarker of genetic susceptibility in assessing an individual's risk of damage from heavy metal exposure.

Key words: PON1; HFE; Lead exposure; Gene polymorphisms; Saudi Arabia

\section{INTRODUCTION}

The heavy metal lead $(\mathrm{Pb})$ is used in various occupational and non-occupational settings (ChemIDplus, 2005) potentially causing elevated blood lead levels (BLLs) in exposed subjects (ATSDR, 2006). A concentration of BLL >10 $\mu \mathrm{g} / \mathrm{dL}$ calls for medical intervention according to the Centers for Disease Control and Prevention (CDC, 2007). Furthermore, gene polymorphisms in genes that influence xenobiotic and iron metabolism may play a major role in determining the genetic susceptibility of a population to xenobiotics (Shaik et al., 2018).

Paraoxonase [(PON) 1; aryldialkylphosphatase (EC 3.1.8.1)] is a phase I xenobiotic-metabolizing enzyme that catalyzes the hydrolysis of many environmental toxicants (Furlong, 2006; Furlong et al., 2008). Gene polymorphisms at codon 55 (leucine/methionine substitution $[\mathrm{T} \rightarrow \mathrm{A}]$, Exon 3, allele 1), and at codon 192 (glutamine /arginine substitution $[\mathrm{A} \rightarrow \mathrm{G}]$, Exon 6 , allele 2) in the PON1 gene affects its enzymatic activity (Mackness et al., 2001). Consequently the serum PON1 levels vary in individuals based on genetic factors. The specific interactions between the heavy metal lead and PON1 enzyme are still not clear, although research indicated that lead at concentrations $<1 \mu \mathrm{M}$, can significantly inhibit PON1 activity in vitro. Moreover, studies in vivo showed that elevated BLLs significantly decreased PON1 activity in lead workers (Li et al., 2006; Yamane et al., 2006; Kamal et al., 2011), more so in subjects with the R192 allele.

The hemochromatosis (HFE) protein is a 343 residue type I transmembrane protein that binds to the transferrin receptor and reduces its affinity for iron-loaded transferrin. Two variants in the HFE gene, C282Y (allele 1) and H63D (allele 2), are commonly found and are associated with of iron overload and could also possibly involve in lead metabolism due to structural similarity (Hansen et al., 2001). As HFE variant alleles are associated with neurodegenerative processes similar to those seen in lead toxicity, it can be hypothesized that the presence of iron enhances the oxidative effects of lead. HFE variant alleles may thus produce a modifying effect BLL toxicokinetics. Subjects with the H63D genotype showed an association between higher BLLs and elevated iron content indicating that carriers of this variant could be susceptible to lead poisoning (Fan et al., 2014). Interestingly studies in children indicated that the H63D and C282Y variants were significantly associated with elevated BLLs (Hopkins et al., 2008), although similar findings could not be reported in adults (Wright et al., 2004; Whitfield et al., 2007). 
The main goal of this study was to evaluate if polymorphisms in HFE and PON1 genes influence BLLs in Saudi workers occupationally exposed to lead. Given the heterogeneity of the Arab populations, and the fact that there is absence of such data from this region, such a study will help in heavy metal toxicity.

\section{MATERIAL AND METHODS}

An observational, cross-sectional study was conducted from February 2015 February 2017, at College of Medicine and King Khaled University Hospital, King Saud University, Riyadh, KSA. Blood samples were collected from male volunteers (19-67 years age) and working in various professions like battery shops, painting industry and automobile repair shops and plumbers in the Riyadh region of Saudi Arabia. All subjects answered a detailed questionnaire related to social and demographic features, disease history, dietary habits, etc. All subjects provided signed informed consent before being included in the study. The study was approved by the departmental research Ethics Review Board (15/0163/IRB) of the KSU. The BLLs were measured by LeadCare II analyzer. Samples were categorized into two goups - High Blood lead level group (High BLL, $>10 \mu \mathrm{g} / \mathrm{dL}$ ) and Low Blood lead level group (Low BLL, $<10 \mu \mathrm{g} / \mathrm{dL})$ based on the guidelines of the Centers for Disease Control and Prevention (CDC, 2007). Gene polymorphisms in the PON1 and HFE genes were evaluated using polymerase chain reaction (PCR) followed by restriction fragment length polymorphism (RFLP).

Genomic DNA was extracted using the QiagenQIAamp DNA Blood Mini Kit from whole blood samples stored in EDTA coated tubes. Genotyping was carried out using PCR-RFLP. The details of primers and fragment sizes can be found in supplementary information. PCR amplification was performed using the QIAGEN HotStarTaq Master Mix Kit at amplification conditions of initial denaturation at $95^{\circ} \mathrm{C}$ for $15 \mathrm{~min}$, and 35 cycles of denaturation at $94^{\circ} \mathrm{C}$ for $1 \mathrm{~min}$, annealing at $60^{\circ} \mathrm{C}$ for 1 min, extension at $72^{\circ} \mathrm{C}$ for $1 \mathrm{~min}$, and final extension at $72^{\circ} \mathrm{C}$ for $10 \mathrm{~min}$. The PCR products were purified using the Bioline Inc., USA kit. RFLP was performed using $1 \mu \mathrm{L}$ each of the respective restriction enzymes were added. The tubes were incubated $(1 \mathrm{~h}$ at $55^{\circ} \mathrm{C}$ for AlwI; $1 \mathrm{~h}$ at $37^{\circ} \mathrm{C}$ for RsaI; and $2 \mathrm{~h}$ at $37^{\circ} \mathrm{C}$ for NlaIII) and heat inactivated for $15 \mathrm{~min}$ at $65-67^{\circ} \mathrm{C}$.

\section{Statistical analysis}

Unless otherwise specified, data are presented as mean \pm SE. Values of $\mathrm{P}<0.05$ were considered statistically significant. Chi-square analysis was used to determine whether the genotype distribution is in Hardy-Weinberg equilibrium, and to compare distributions of alleles and genotypes. Statistical analyses were performed using the Systat statistical package and the MedCalc statistical program. 


\section{RESULTS}

In the current study, male subjects aged (19 - 67 years; mean age: 32.9 - 35.8 years) were included. A total of 20 subjects had BLLs of $>10 \mu \mathrm{g} / \mathrm{dL}$ and the remaining subjects had $<10 \mu \mathrm{g} / \mathrm{dL}$. The mean BLLs were $4.37 \mu \mathrm{g} / \mathrm{dL}$ and $18.12 \mu \mathrm{g} / \mathrm{dL}$ in the low and high BLL groups, respectively $(\mathrm{P}<0.001)$. In the high BLL group and in the overall population, the genotype frequencies were consistent with Hardy-Weinberg equilibrium (Table 1).

Table 1. The distribution of genotypes and allele frequencies in the occupationally exposed lead workers.

\begin{tabular}{|c|c|c|c|c|c|}
\hline & & $\begin{array}{l}\text { Genotype } \\
\text { frequency }(\%)\end{array}$ & $\begin{array}{l}\text { Allele } \\
\text { frequency }\end{array}$ & Chi square & $\begin{array}{l}\text { Chi square } \\
\text { P value }\end{array}$ \\
\hline \multirow{2}{*}{ PON1 allele 1} & $\mathrm{TT}$ & 63.4 & $\mathrm{~T}=0.759$ & \multirow{2}{*}{0.38} & \multirow{2}{*}{0.53} \\
\hline & $\mathrm{TA}+\mathrm{AA}$ & 36.5 & $\mathrm{~A}=0.24$ & & \\
\hline \multirow{2}{*}{ PON1 allele 2} & AA & 91.2 & $A=0.959$ & \multirow{2}{*}{0.22} & \multirow{2}{*}{0.6} \\
\hline & $\mathrm{AG}+\mathrm{GG}$ & 8.8 & $\mathrm{G}=0.04$ & & \\
\hline \multirow{2}{*}{ HFE allele 1} & $\mathrm{CC}$ & 98.3 & $\mathrm{C}=0.99$ & \multirow{2}{*}{0.008} & \multirow{2}{*}{0.92} \\
\hline & $\mathrm{CG}+\mathrm{GG}$ & 1.6 & $\mathrm{G}=0.008$ & & \\
\hline \multirow{2}{*}{ HFE allele 2} & GG & 100 & $\mathrm{G}=1$ & \multirow{2}{*}{ NA } & \multirow{2}{*}{ NA } \\
\hline & $\mathrm{GA}+\mathrm{AA}$ & 0 & $\mathrm{~A}=0$ & & \\
\hline
\end{tabular}

NA $=$ not applicable.

The genotype frequencies of the all tested SNPs in the low BLL and high BLL groups are presented in Tables 2 and 3, respectively. The distribution of genotypes of PON1-L55M in the low BLL group deviated from the Hardy-Weinberg equilibrium. The frequency of the dominant genotypes of PON1-allele 1 - TT, PON1- allele 2 - AA, HFE- allele 1 - CC, HFE- allele 2 - GG were 63.4, 91.2, 98.3, and 100\% respectively, for the overall population.

Table 2. The distribution of genotypes and allele frequencies in occupationally exposed lead workers with normal blood lead levels.

\begin{tabular}{|c|c|c|c|c|c|}
\hline & & $\begin{array}{l}\text { Genotype } \\
\text { frequency }(\%)\end{array}$ & $\begin{array}{l}\text { Allele } \\
\text { frequency }\end{array}$ & Chi square & $\begin{array}{l}\text { Chi square } \\
\text { P value }\end{array}$ \\
\hline \multirow{3}{*}{ PON1 allele 1} & TT & 71.8 & $\mathrm{~T}=0.830$ & & \\
\hline & TA & 22.3 & $A=0.169$ & 4.47 & 0.034 \\
\hline & $\mathrm{AA}$ & 5.8 & & & \\
\hline \multirow{3}{*}{ PON1 allele 2} & AA & 91.1 & $\mathrm{~A}=0.955$ & & \\
\hline & $\mathrm{AG}$ & 8.8 & $\mathrm{G}=0.044$ & 0.21 & 0.64 \\
\hline & GG & 0 & & & \\
\hline \multirow{3}{*}{ HFE allele 1} & $\mathrm{CC}$ & 98 & $\mathrm{C}=0.99$ & & \\
\hline & CG & 2 & $\mathrm{G}=0.01$ & 0.01 & 0.94 \\
\hline & GG & 0 & & & \\
\hline \multirow{3}{*}{ HFE allele 2} & GG & 100 & $\mathrm{G}=1$ & & \\
\hline & GA & 0 & $\mathrm{~A}=0$ & NA & NA \\
\hline & $\mathrm{AA}$ & 0 & & & \\
\hline
\end{tabular}

NA = not applicable. 
Table 3. The distribution of genotypes and allele frequencies in occupationally exposed lead workers with high blood lead levels.

\begin{tabular}{llllll}
\hline & & $\begin{array}{l}\text { Genotype frequency } \\
(\boldsymbol{\%})\end{array}$ & $\begin{array}{l}\text { Allele } \\
\text { frequency }\end{array}$ & Chi square & $\begin{array}{l}\text { Chi square } \\
\text { P value }\end{array}$ \\
\hline & TT & 20 & $\mathrm{~T}=0.52$ & & \\
PON1 allele 1 & TA & 65 & $\mathrm{~A}=0.47$ & 1.83 & \\
& AA & 15 & $\mathrm{~A}=0.97$ & & \\
PON1 allele 2 & AA & 95 & $\mathrm{G}=0.02$ & 0.012 & 0.91 \\
& AG & 5 & $\mathrm{~T}=1$ & \\
HFE allele 1 & GG & & $\mathrm{C}=0$ & $\mathrm{NA}$ & $\mathrm{NA}$ \\
& CC & 100 & & & \\
HFE allele 2 & GG & & $\mathrm{G}=1$ & $\mathrm{NA}$ \\
& GG & 100 & $\mathrm{~A}=0$ & $\mathrm{~N}$
\end{tabular}

$\mathrm{NA}=$ not applicable

Overall, the genetic variants, TA and AA in the PON1-allele 1 were found to be significantly associated with a risk of developing lead poisoning with the minor allele 'A' being a risk factor $\left(\mathrm{OR}=4.420, \chi^{2}=18.2, \mathrm{P}=0.00002\right)$ (Table 4). None of the other genotypes/alleles for the PON1-allele 2 -AA, HFE-allele 1- CC, HFE- allele 2 - GG SNPs were significantly associated with lead toxicity (Table 4). All subjects from the high BLL group had significantly higher BLLs than the low BLL group. The results are presented in Figure 1.

Table 4. Distribution of genotype and allele frequencies in occupationally exposed lead workers with low vs high blood lead levels.

\begin{tabular}{|c|c|c|c|c|}
\hline SNP ID & Genotype & OR (95\% CI) & $\chi^{2}$-Value & P- Value \\
\hline \multirow{6}{*}{ PON1-allele 1} & TT & Ref & & \\
\hline & TA & $10.457[3.104-35.221]$ & 18.63 & 0.00002 \\
\hline & AA & $9.250[1.669-51.276]$ & 8.68 & 0.00322 \\
\hline & \multicolumn{4}{|c|}{ Allele frequency difference } \\
\hline & $\mathrm{T}$ & Ref & & \\
\hline & A & $4.420[2.153-9.075]$ & 18.2 & 0.00002 \\
\hline \multirow{6}{*}{ PON1-allele 2} & AA & Ref & & \\
\hline & AG & $0.517[0.062-4.312]$ & 0.38 & 0.531 \\
\hline & GG & $4.561[0.088-236.630]$ & NA & 0.913 \\
\hline & \multicolumn{4}{|c|}{ Allele frequency difference } \\
\hline & A & Ref & & \\
\hline & G & $0.528[0.065-4.286]$ & 0.37 & 0.671 \\
\hline \multirow{6}{*}{ HFE1-allele 1} & $\mathrm{CC}$ & Ref & & \\
\hline & CG & $1.010[0.047-21.871]$ & 0.39 & 0.534 \\
\hline & GG & $5.051[0.097-262.318]$ & NA & 0.989 \\
\hline & \multicolumn{4}{|c|}{ Allele frequency difference } \\
\hline & $\mathrm{C}$ & Ref & & \\
\hline & G & $1.031[0.049-21.903]$ & 0.38 & 0.788 \\
\hline \multirow{6}{*}{ HFE-allele 2} & GG & Ref & & \\
\hline & GA & $4.689[0.091-242.610]$ & NA & 0.978 \\
\hline & AA & $4.689[0.091-242.610]$ & NA & 0.978 \\
\hline & \multicolumn{4}{|c|}{ Allele frequency difference } \\
\hline & $\mathrm{G}$ & Ref & & \\
\hline & A & $4.730[0.093-241.590]$ & NA & 0.994 \\
\hline
\end{tabular}

$\mathrm{NA}=$ not applicable 


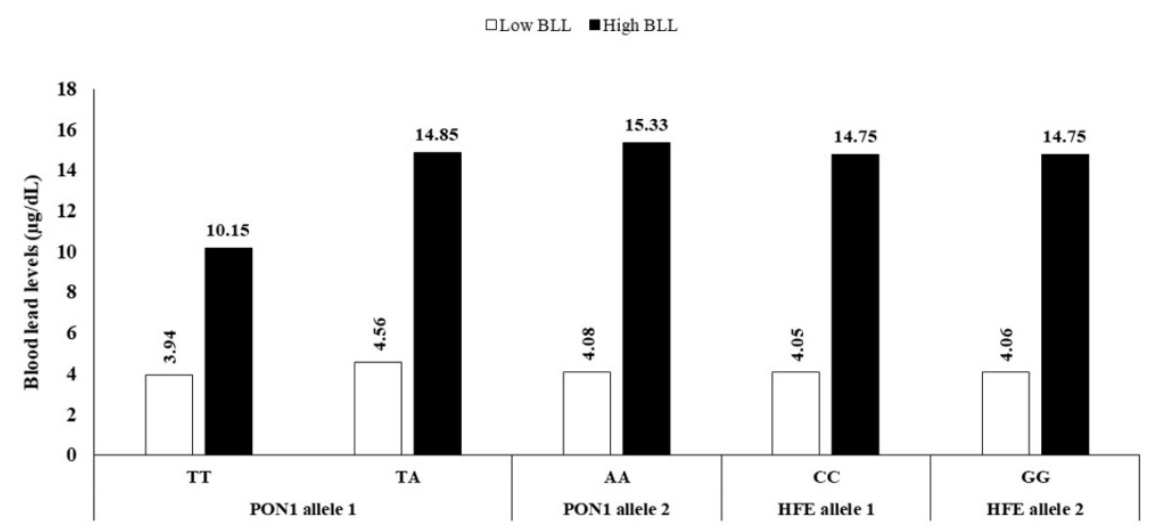

Figure 1. Blood lead levels (BLL) in occupationally exposed lead workers categorized by genotypes.

\section{DISCUSSION}

Pharmacogenetic studies of subjects exposed to heavy metals help to evaluate the genetic susceptibility of subjects and devise appropriate treatment regimen (IngelmanSundberg, 2001). We evaluated the association of PON1 and HFE gene polymorphisms with BLLs. To the best of our knowledge, similar studies from the Middle-Eastern region, especially Saudi Arabia are minimal/absent. Moreover, because the Saudi population has unique ethnicity and socio-demographic characteristics, it is even more important to understand these parameters.

In this study, the subjects were categorized as low BLL group $(<10 \mu \mathrm{g} / \mathrm{dL})$ or high BLL group ( $>10 \mu \mathrm{g} / \mathrm{dL})$ as per CDC guidelines (CDC, 2007). Furthermore, two genes, PON1 and HFE were selected for genetic susceptibility testing. Most of the subjects had BLLs of $4.37 \mu \mathrm{g} / \mathrm{dL}$; however, the levels went up to $18.12 \mu \mathrm{g} / \mathrm{dL}(\mathrm{P}<0.001)$ in the high BLL group subjects. Except for the PON1 L55M polymorphism in the low BLL group, all other polymorphisms were in Hardy-Weinberg equilibrium.

Studies on genes that are involved in the metabolic pathway directly or indirectly can help in understanding genetic susceptibility and potentially identify biomarkers of susceptibility. Two such genes of importance are the PON1 and HFE. PON1 is shown to participate in the hydrolysis of xenobiotics but the enzyme activity varies based on the presence of polymorphisms. This variability is due to SNPs in the coding region of PON1 gene at positions 55 (L to M) and 192 (Q to R) (Scacci et al., 2003; Morcos et al., 2015). There is a scarcity of data on the effect of PON1 polymorphisms in subjects who are occupationally exposed to heavy metals. Research indicates that the L55 isoform is more stable and resistant to proteolysis leading to higher PON1 levels (Harel et al., 2004).

In the current study, we evaluated the relationship between PON1 genetic polymorphisms and BLLs in 127 subjects occupationally exposed to lead. Significant differences in the genotype and allele frequencies of PON1 gene were observed in the low BLL group $(\mathrm{P}=0.03)$. The presence of AA genotype and A allele were found to be a significant risk factor for BLLs. The genotypes of PON1 Q192R were not significantly altered and the alleles were not found to be a significant risk factor for BLLs. 
It has been shown that a decrease in PON1 activity can occur in individuals exposed to heavy metal lead which can render subjects to atherosclerosis - this was especially with respect to the R192 allele (Li et al., 2006; Kamal et al., 2007; Kamal et al., 2011). However, the relevance of this finding has to be explored further owing to the significant protective role of PON1. Interestingly, in vitro studies have shown that lead can inhibit the activity of PON1 (Cole et al., 2002; Debord et al., 2003). In the study reported by Li et al. (2006), BLLs of $27 \mu \mathrm{g} / \mathrm{dL}$ were reported in contrast to the lower levels reported in our study. The years and intensity of exposure could be the major factors in determining BLLs. Moreover, a considerable decrease in PON1 function has also been reported in women exposed to lead (Pollack et al., 2014). It should be emphasized that the mechanisms governing inhibition of PON1 activity by heavy metals is still unclear. Because of the likelihood of metal ions to bind to $-\mathrm{SH}$ groups, and due to the fact that PON1 enzyme has a cysteine residue albeit not at the active site for enzyme, the binding of metals to the free -SH group can destabilize and alter the functioning of the molecule (Harel et al., 2004). This can impact not only the hydrolytic activity of PON1 but also its role in antioxidant activity (Permpongpaiboon et al., 2011). Additionally, it has been hypothesized that PON1 and esterase activities could be modulated by exposure to metal compounds causing potentially increased expression of PON1 against xenobiotics (Hernández et al., 2009).

Another gene that has been evaluated in this study is the HFE gene which is associated with excessive iron accumulation. Because polymorphisms in HFE gene can effect bone mineralization, it can be expected that genetic variants may also influence lead accumulation in the body. However, in the current study, we could not find any association between the genotypes and BLLs for both the HFE SNPs tested. This could be due to the small sample sizes and discrepancy in the number of low BLL and high BLL subjects.

Genetic variants in the HFE gene especially the C282Y variant and H63D variant play important roles in iron metabolism and hemochromatosis (Fan et al., 2014). Although not consistent with this study, a higher BLL was found in workers with H63D variant indicating that this genotype modifies the association of iron and lead irrespective of the $C 282 Y$ allele. It has been hypothesized in this study that the H63D variant promotes excess iron stores, and lead absorption may elevate BLLs. Similar to this study on Asian subjects, no $\mathrm{C} 282 \mathrm{Y}$ variant was found in our study population. Moreover, consistent to our results, another study in the Saudi population (Alsmadi et al., 2006) indicated a very low incidence of the $\mathrm{C} 282 \mathrm{Y}$ in contrast to other populations (Burke et al., 2000; Gochee et al., 2002). Because HFE gene is an important modifier of iron, it can also modify lead absorption and storage. As the heavy metal lead shares the same metabolic pathway as iron, the presence of HFE polymorphisms may upregulate or down regulate divalent cation transporters (Zhu et al., 2013; Wright et al., 2004).

Research has indicated that the $\mathrm{H} 63 \mathrm{D}$ and the $\mathrm{C} 282 \mathrm{Y}$ variants are significantly associated with BLLs in young children (Hopkins et al., 2008); however, similar results were not found in the older subjects (Wright et al., 2004; Whitfield et al., 2006). In the current study and the studies by Wright et al. (2004); Whitfield et al. (2006), HFE genotypes were not directly associated with BLLs; however, further studies in larger sample sizes and across various populations are needed to confirm the association. Interestingly, using a combination of genotyping, histochemistry and biochemical analyses, Martinelli et al. (2013) have provided preliminary evidence of the protective role of PON1 in hereditary 
hemochromatosis. PON1 expression in the liver of hereditary hemochromatosis was found to be increased owing to the inherently increased oxidative stress in these subjects.

These results are novel since this is the first study to the best of our knowledge conducted in Saudi subjects from these occupations. Studies conducted in Saudi Arabia primarily focused on non-occupationally exposed children and adults/healthy volunteer subjects. A study by Al-Saleh (1995) in Saudi male volunteers reported a cut-off range of $12 \mu \mathrm{g} / \mathrm{dL}$ with concentrations being higher in smokers. More recently, a study conducted in healthy volunteers from Al-Batha and Olya regions of Riyadh, approximately $17.5-52.2 \%$ subjects had BLL $>10 \mu \mathrm{g} / \mathrm{dL}$ (Al- Othman et al., 2013). Thus, this study conclusively established that close to $25 \%$ of occupationally exposed subjects had BLL $>10 \mu \mathrm{g} / \mathrm{dL}$. Gene-environment association studies are rare especially in this part of the Middle East; hence, such studies are needed to examine the importance of polymorphisms in various genes and their link to susceptibility to environmental toxicants.

\section{ACKNOWLEDGMENTS}

We thank all the volunteers who participated in this study. We thank Etico Research Pvt. Ltd, Hyderabad, India for scientific/editorial assistance in the preparation of this manuscript. We would like to extend our sincere appreciation to the National Science Technology and Innovation plan NSTIP strategic technologies programs, project number NPST-11MED1919-02, Kingdom of Saudi Arabia for funding this work.

\section{CONFLICTS OF INTEREST}

The authors declare no conflict of interest.

\section{DATA AVAILABILITY}

Data pertaining to this study is currently being analyzed for other complementary genes and confounding factors. Data can be made available in the public domain for the readers only after all manuscripts for this project have been published.

\section{REFERENCES}

Al-Othman A (2013). Lead in drinking water and human blood in Riyadh City, Saudi Arabia. Arab. J. Geosci. 6: 31033109.

Al-Saleh I (1995). Lead exposure in Saudi Arabia and its relationship to smoking. Biometal. 8: 243-245.

Alsmadi OA, Al-Kayal F, Al-Hamed M and Meyer BF (2006). Frequency of common HFE variants in the Saudi population: a high throughput molecular beacon-based study. BMC Med. Genet. 7: 43.

ATSDR (2006). Agency for Toxic Substances and Disease Registry. Interaction profile for chlorpyrifos, lead, mercury, and methylmercury. Atlanta, GA. pp 54-100.

Burke W, Imperatore G, McDonnell SM, Baron RC, et al. (2000). Contribution of different HFE genotypes to iron overload disease: a pooled analysis. Genet. Med. 2: 271-277.

CDC (2007) (Centers for Disease Control and Prevention) Advisory Committee on Childhood Lead Poisoning Prevention. Interpreting and managing blood lead levels $<10 \mu \mathrm{g} / \mathrm{dL}$ in children and reducing childhood exposures to lead: recommendations of CDC's Advisory Committee on Childhood Lead Poisoning Prevention. MMWR Recomm. Rep. 56: n1-16.

ChemIDplus (2005). Lead and Lead Compounds. Bethesda, Md, USA: U.S. National Library of Medicine.

Cole TB, Li WF, Richter RJ, Furlong CE, et al. (2002). Inhibition of paraoxonase (PON1) by heavy metals. Toxicol. Sci. 66: 312 . 
Debord J, Bollinger JC, Merle L and Dantoine T (2003). Inhibition of human serum arylesterase by metal chlorides. J. Inorg. Biochem. 94(1-2): 1-4.

Fan G, Du G, Li H, Lin F, et al. (2014). The effect of the hemochromatosis (HFE) genotype on lead load and iron metabolism among lead smelter workers. PLoS ONE. 9(7): e101537.

Furlong C, Holland N, Richter R, Bradman A, et al. (2006). PON1 status of farm-worker mothers and children as a predictor of organophosphate sensitivity. Pharmacogenet Genomics. 16: 183-190.

Furlong CE, Richter RJ, Li W-F, Brophy VH, et al. (2008). The functional consequences of polymorphisms in the human PON1 gene. In: Mackness B, Mackness M, Aviram M, Paragh G, editors. The Paraoxonases: Their Role in Disease, Development and Xenobiotic Metabolism. Dordrecht, The Netherlands: Springer; pp 267-281.

Gochee PA, Powell LW, Cullen DJ, Du Sart D, et al. (2002). A population-based study of the biochemical and clinical expression of the H63D hemochromatosis mutation. Gastroenterol. 122: 646-651.

Hanson EH, Imperatore G, Burke W. (2001). HFE gene and hereditary hemochromatosis: a HuGE review. Human Genome Epidemiology. Am. J. Epidemiol. 154: 193-206.

Harel M, Aharoni A, Gaidukov L, Brumshtein B, et al. (2004). Structure and evolution of the serum paraoxonase family of detoxifying and anti-atherosclerotic enzymes. Nat. Struct. Mol. Biol. 5: 412-9.

Hernández AF, Gil F, Leno E, López O, et al. (2009). Interaction between human serum esterases and environmental metal compounds. Neurotoxicol. 30: 628-635.

Hopkins MR, Ettinger AS, Hernandez-Avila M, Schwartz J, et al. (2008). Variants in iron metabolism genes predict higher blood lead levels in young children. Environ. Health Perspect. 116: 1261-1266.

Ingelman-Sundberg M (2001). Genetic variability in susceptibility and response to toxicants. Toxicol. letters. 120: 25968.

Kamal M, Fathy MM, Taher E, Hasan M, et al. (2011). Assessment of the role of paraoxonase gene polymorphism (Q192R) and paraoxonase activity in the susceptibility to atherosclerosis among lead-exposed workers. Ann. Saudi Med. 31(5): 481-487.

Kamal M, Fathy MM, Taher E, Elkhatin M, et al. (2007). Serum Paraoxonase 1 (PON1) Activity and Genotype in Occupationally Lead-Exposed Egyptian Workers. Int. J. Occup. Environ. Med. 13(3-4): 267-298.

Li WF, Pan MH, Chung MC, Ho CK, et al. (2006). Lead exposure is associated with decreased serum paraoxonase 1 (PON1) activity and genotypes. Environ. Health Perspect. 114(8): 1233-1236.

Mackness B, Davies GK, Turkie W, Lee E, et al. (2001). Paraoxonase status in coronary heart disease: are activity and concentration more important than genotype? Arterioscler. Thromb. Vasc. Biol. 21: 1451-1457.

Martinelli N, García-Heredia A, Roca H, Aranda N, et al. (2013). Paraoxonase-1 status in patients with hereditary hemochromatosis. J. Lipid. Res. 54: 1484-1492.

Morcos NYS, El-Masry MK, Moustafa MK and Galal SY (2015). Contrasting genetic influence of PON 1 coding gene polymorphisms L55M and Q192R on individuals' response to environmental agents. Egypt. J. Med. Hum. Genet. 16: 233-237.

Permpongpaiboon T, Nagila A, Pidetcha P, Tuangmungsakulchai K, et al. (2011). Decreased paraoxonase 1 activity and increased oxidative stress in low lead-exposed workers. Human Exptl. Toxicol. 30: 1196-1203.

Pollack AZ, Sjaarda L, Ahrens KA, Mumford SL, et al. (2014). Association of Cadmium, Lead and Mercury with Paraoxonase 1 Activity in Women. PLoS ONE. 9: e92152.

Scacchi R, Corbo RM, Rickards O and De Stefano GF (2003). New data on the world distribution of paraoxonase (PON1 Gln 192 --> Arg) gene frequencies. Hum. Biol. 75: 365-73.

Shaik AP, Alsaeed AH, Sultana A, Faiyaz-Ul-Haque M, et al. (2018). A study on ALAD (G177C and T168C) and MGP (T-138C) gene polymorphisms associated with lead exposure in subjects from Saudi Arabia. Int. J. Adv. Appl. Sc. 5(3): 53-59.

Whitfield JB, Dy V, McQuilty R, Zhu G, et al. (2007). Evidence of genetic effects on blood lead concentration. Environ. Health Perspect. 115: 1224-1230.

Wright RO, Silverman EK, Schwartz J, Tsaih SW, et al. (2004). Association between hemochromatosis genotype and lead exposure among elderly men: The normative aging study. Environ Health Perspect. 112: 746-750.

Yamane T, Matsumoto T, Nakae I, Takashima H, et al. (2006). Impact of paraoxonase polymorphism (Q192R) on endothelial function in intact coronary circulation. Hypertens. Res. 29: 417-422.

Zhu G, Fan G, Feng C, Li Y, et al. (2013). The effect of lead exposure on brain iron homeostasis and the expression of DMT1/FP1 in the brain in developing and aged rats. Toxicol. Lett. 216: 108-123. 